StanisŁaW SALA

Akademia Świętokrzyska, Kielce

\title{
Wpływ procesów globalizacji na region
}

Etymologicznie pojęcie region wywodzi się z łaciny, gdzie jest kojarzone z dwoma słowami: regio - królestwo, kraj oraz rego - rządzić. Pierwotnie pojęciem tym oznaczano obszar znajdujący się pod rządami króla czy namiestnika. Obecnie pojęcie to jest wykorzystywane w różnych naukach i bardzo różnie definiowane (Gorzelak 1998; Kondracki 1995; Koter 1995; Massalski 1930; Wilczyński 1997; Wilk 1994; Chojnicki 1999; Rykiel 2006). Można jednak wyróżnić pewne wspólne elementy różnych definicji.

Pojęcie regionu jest zawsze łączone $\mathrm{z}$ określonym terytorium czy obszarem rozumianym jako część państwa, kontynentu czy świata. Determinantą wyróżniającą region są pewne specyficzne cechy fizyczno-geograficzne, społeczno-ekonomiczne lub polityczne pozwalające na delimitację określonego obszaru. W naukach geograficznych najczęściej regiony wydziela się ze względu na określone kryteria (tab. 1), którym może być pojedyncza cecha, zespół cech lub zmiana natężenia danej cechy. W tradycyjnym ujęciu regiony są wydzielane ze względu na kryteria historyczno-etnograficzne. W Polsce jako przykład może posłużyć Śląsk, Wielkopolska czy Pomorze, a w Europie - Katalonia, Bawaria czy Bretania (Sala 2005, 2006).

Tabela 1. Główne kryteria wydzielania regionów

\begin{tabular}{|l|l|l|}
\hline \multicolumn{1}{|c|}{ Typy regionów } & \multicolumn{1}{c|}{$\begin{array}{c}\text { Kryterium } \\
\text { wyróżnienia regionów }\end{array}$} & \multicolumn{1}{c|}{ Nazwy przykładowych regionów } \\
\hline Turystyczne & Walory turystyczne & Mazury \\
\hline Etnograficzne & Grupa etnograficzna & Region kielecki \\
\hline Etniczne & Grupa etniczna & Kraj Basków, Zulu Land, Kurdystan \\
\hline Kulturowe & Grupa kulturowa & Region śródziemnomorski \\
\hline Fizyczno-geograficzne & Cechy fiz.-geogr. & Nizina Amazonki \\
\hline Geologiczne & Formacja skalna & Fennoskandia, Kaledonidy \\
\hline Polityczne & Cechy polityczne & Bliski Wschód \\
\hline Historyczne & Tradycje historyczne & Lotaryngia, Wielkopolska, Mazowsze \\
\hline Administracyjne & Jednostka administracyjna & Woj. świętokrzyskie, \\
\hline Językowe & Rodzina językowa & Latynoameryka, Angloameryka \\
\hline Gospodarcze & Okręg gospodarczy & Zagłębie Donieckie, Dolina Krzemowa \\
\hline Zoogeograficzne & Kraina zoogeograficzna & Kraina Orientalna, Paleoarktyka \\
\hline Fitogeograficzne & Kraina fitogeograficzna & Campos, Miombo, Mopane \\
\hline
\end{tabular}




\section{Polityczne KonseKWEnCJE PROCESÓW GLOBALIZACJI DLA REGIONU}

Wraz z trzecią fazą natężenia procesów globalizacji w Europie wzrasta zainteresowanie problematyką dotyczącą regionów. Procesy globalizacji bardzo silnie oddziaływają na poszczególne regiony. Można stwierdzić, że wyznaczają one warunki brzegowe dla rozwoju społeczno-gospodarczego regionów. Konsekwencje procesów globalizacji dla regionów są natury politycznej, gospodarczej oraz społecznej i przyczyniają się nie tylko do zmian gospodarczych czy politycznych, ale także zmieniają społeczeństwo dokonując przewartościowań postaw i poglądów ludzi (Jędrzejczyk 2002).

Wzrost znaczenia regionów jest konsekwencją słabnącej roli państwa, który to proces jest często nazywany erozją państwa narodowego (Ohmae 1995). Często mówi się, że państwo jest organizmem politycznym zbyt dużym, aby dostrzegać i skutecznie rozwiązywać lokalne, regionalne problemy. Państwo systematycznie zatraca swoją autonomię przekazując swoje uprawnienia na wyższy, międzynarodowy oraz niższy, regionalny poziom (Hirst, Tompson, Cable 1995). Przeniesienie mocy decyzyjnych ze szczebla centralnego na szczebel regionalny z jednej strony wpływa na lepsze wykorzystanie potencjału regionalnego, natomiast z drugiej - pozwala szybciej i skuteczniej przeciwdziałać negatywnym konsekwencjom działalności korporacji, a decentralizacja środków finansowych pozwala na lepsze ich lokalne wykorzystanie. Za główną przyczynę spadku znaczenia państwa należy uznać działalność korporacji transnarodowych (KTN), z którymi zbiurokratyzowane państwa coraz trudniej sobie radzą. Szansę na lepsze zarządzanie oraz wykorzystanie funduszy daje region, powoli stający się strukturą bardziej efektywną, lepiej od państwa radzącą sobie w warunkach narzuconych przez procesy globalizacji.

Polityka regionalna w Europie stwarza szansę na znaczne wzmocnienie roli regionów poprzez zasadę subsydiarności oraz lobbingu. Rosnąca rola regionów w Europie znalazła swoje odzwierciedlenie w powołanym na podstawie Traktatu z Maastricht Komitecie Regionów. Dotychczas Komitet Regionów posiada jedynie zdolności opiniotwórcze, można się jednak spodziewać, że wraz z upływem czasu zostanie on wyposażony w instrumenty pozwalające na skuteczne działanie, znacznie zwiększające jego zakres kompetencji. W ostatnich latach wzrasta liczba regionów, które poprzez lobbing próbują wpływać na prace Parlamentu Europejskiego czy Komisji Europejskiej (Gawlikowska-Hueckel 2002).

Zjednoczona Europa nie ma być związkiem coraz słabszych państw, lecz związkiem coraz silniejszych regionów. Tylko taka konstrukcja polityczna będzie skutecznie chronić zróżnicowanie kulturowe i etniczne Europy oraz promować gospodarkę regionalną. Położenie akcentu na region pozwoli ożywić regiony najsłabiej rozwinięte, całymi wiekami zaniedbywane przez rządy centralne. Regiony próbują wpływać na korzystne dla nich decyzje unijne. W niedalekiej przyszłości, w konfrontacji na płaszczyźnie ekonomicznej z korporacjami transnarodowymi, mówiące jednym głosem regiony mogą stanowić siłę, z którą będą się liczyły nawet najpotężniejsze korporacje.

Reforma administracyjna w Polsce, w efekcie której utworzono 16 województw, jest rezultatem procesu dostosowywania polskiej polityki regionalnej do standardów Unii Europejskiej. Polskie czy europejskie regiony mają długą historię i niepowtarzalną szansę na realizację własnych przedsięwzięć. Jednym z podstawowych celów Unii Europejskiej jest dążenie do społeczno-gospodarczej jedności poszczególnych regionów, co znalazło swe odniesienie w utworzeniu Komitetu Regionów - organu doradczego Rady i Komisji 
Europejskiej. Poprzez wspólną reprezentację regiony są w stanie uzyskać większe fundusze na rozwój, a tym samym skutecznie stawić czoła negatywnym konsekwencjom procesów globalizacji. W nomenklaturze, dla celów statystycznych, poziom regionalny określono jako NUTS 2 (The Nomenclature of Territorial Units for Statistics) (tab. 2). Przyjęto, że obszary chcące pretendować do rangi regionów winny spełniać następujące kryteria:

- posiadać jednolity obszar administracyjny,

- dysponować własnym budżetem regionalnym,

- posiadać władzę publiczną pochodzącą z wolnych wyborów, a w tym organ wykonawczy odpowiedzialny przed reprezentacją polityczną samorządu terytorialnego.

Koncepcja regionu przyjęta przez Unię Europejską jest bardzo ogólna i można ją przyjąć jako punkt wyjścia dla naszych dalszych rozważań.

Tabela 2. Zróżnicowanie regionalne Unii Europejskiej oraz krajów kandydackich i na poziomie NUTS $2 \mathrm{w} 2000 \mathrm{r}$.

\begin{tabular}{|c|c|c|c|}
\hline \multirow[b]{2}{*}{ Nazwa kraju } & \multirow[b]{2}{*}{$\begin{array}{c}\text { Liczba jednostek } \\
\text { NUTS } 2\end{array}$} & \multicolumn{2}{|c|}{ Średnia wielkość jednostki NUTS 2} \\
\hline & & $\begin{array}{l}\text { Powierzchnia } \\
\left(\text { w tys. } \mathbf{k m}^{2} \text { ) }\right.\end{array}$ & $\begin{array}{l}\text { Liczba ludności } \\
\quad \text { (w mln) }\end{array}$ \\
\hline Austria & 9 & 9 & 0,9 \\
\hline Belgia & 11 & 3 & 0,9 \\
\hline Bułgaria & 6 & 18 & 1,4 \\
\hline Cypr & 1 & 9,25 & 0,7 \\
\hline Czechy & 8 & 10 & 1,3 \\
\hline Dania & 1 & 43,1 & 5,4 \\
\hline Estonia & 1 & 45,2 & 1,4 \\
\hline Finlandia & 6 & 56 & 0,9 \\
\hline Francja & 22 & 21 & 2,6 \\
\hline Grecja & 13 & 10 & 0,8 \\
\hline Hiszpania & 18 & 28 & 2,2 \\
\hline Holandia & 12 & 3 & 1,3 \\
\hline Irlandia & 1 & 70,3 & 3,9 \\
\hline Litwa & 1 & 65,2 & 3,6 \\
\hline Luksemburg & 1 & 2,6 & 0,4 \\
\hline Łotwa & 1 & 64,6 & 2,3 \\
\hline Malta & 1 & 0,3 & 0,4 \\
\hline Niemcy & 40 & 9 & 2,1 \\
\hline Polska & 16 & 20 & 2,4 \\
\hline Portugalia & 7 & 13 & 1,4 \\
\hline Rumunia & 8 & 30 & 2,8 \\
\hline Słowacja & 4 & 12 & 1,3 \\
\hline Słowenia & 1 & 20,3 & 1,9 \\
\hline Szwecja & 8 & 56 & 1,1 \\
\hline Węgry & 7 & 13 & 1,5 \\
\hline Wlk. Brytania & 37 & 7 & 1,6 \\
\hline Włochy & 20 & 15 & 2,9 \\
\hline
\end{tabular}

Źródło: Domański, Guzik, Micek 2003, s. 127 (zmienione) 


\section{GospodARCZE KONSEKWENCJE PROCESÓW GLOBALIZACJI DLA REGIONU}

Na rynku obserwujemy silną rywalizację pomiędzy poszczególnymi regionami, wspartą staraniami państwa, mającymi na celu przyciągnięcie na swój obszar jak najwięcej kapitału korporacyjnego. W obliczu procesów globalizacji małe i dysponujące stosunkowo niewielkimi funduszami regiony znajdują się w bardzo ciężkim położeniu. Uwzględniając olbrzymi kapitał jakim dysponują poszczególne korporacje transnarodowe, trudno się spodziewać, aby regiony były traktowane jako równorzędny partner.

Funkcjonowanie korporacji transnarodowych ponad granicami państw wywołuje efekt wyrównywania się kosztów pracy w skali globalnej. Z jednej strony pracownicy niewykwalifikowani $\mathrm{w}$ regionach słabo rozwiniętych zarabiają w korporacjach nieco więcej niż w pozostałych przedsiębiorstwach, z drugiej natomiast obserwujemy spadek zarobków w analogicznej klasie w regionach wysoko rozwiniętych. W konsekwencji regiony bogate przeżywają coraz większy kryzys, będący efektem konkurencji ze strony biednych regionów. Dobrym przykładem jest Kalifornia, uchodząca za jeden z najlepiej rozwiniętych regionów świata. Obecnie przeżywa duże problemy wynikające z powiększającej się dziury budżetowej, związanej z odpływem kapitału do innych części świata. Problemy finansowe zmusiły gubernatora do podjęcia specyficznych działań, zmierzających do zachowania status quo. $\mathrm{Na}$ szeroką skalę rozwijany jest program budowy więzień, co w przyszłości ma zapewnić większe wpływy do budżetu. Aby zapewnić sobie odpowiednio wysoką liczbę więźniów, wprowadzono poprawki do lokalnego prawodawstwa zaostrzające przepisy prawa karnego (np. za potrójną recydywę skazaniec otrzymuje karę 25 lat pozbawienia wolności).

W dobie globalizacji regiony dysponujące drogą siłą roboczą popadają w coraz większe problemy finansowe, a regiony biedne stoją przed dużą szansą na poprawę swojej egzystencji poprzez większą zdolność przyciagania na swój obszar korporacji szukających taniej siły roboczej. W wyniku tego obserwujemy coraz dynamiczniejszy rozwój regionów, znajdujących się w krajach rozwijających się, takich jak Chiny czy Indie.

Procesy globalizacji prowadzą do bardzo dużej polaryzacji regionalnych dochodów pomiędzy kadrą zarządzającą a pozostałymi pracownikami. W latach siedemdziesiątych różnica między płacą szefów korporacji a pracowników niewykwalifikowanych wynosiła 44 razy, w końcu lat 90. doszła do 320 razy, a obecnie kształtuje się na poziomie ponad 530 razy więcej (Szymański 2001; Grefe, Greffrath, Schumann 2004). Lawinowo rosnące zarobki szefów i właścicieli korporacji doprowadziły do kumulacji niewyobrażalnego bogactwa w rękach nielicznych jednostek. W 1998 r. majątek trzech najbogatszych osób na świecie był większy niż suma PKB 48 najbiedniejszych krajów rozwijających się, liczących około 600 mln osób. Majątek 15 najbogatszych przekracza PKB całej Afryki Subsaharyjskiej, majątek 32 najbogatszych przekracza PKB Południowej Azji, natomiast majątek 84 najbogatszych ludzi przekracza PKB Chin, najbardziej zaludnionego kraju naszej planety. 14 osób w Japonii posiada majątek wart 41 miliardów dolarów. W USA 42\% majątku narodowego jest własnością 1\% populacji. Obecnie na świecie 800 milionów ludzi cierpi głód. Niemal miliard żyje za mniej niż jednego dolara dziennie. Społeczne rozwarstwienie na skalę globalną to nie tylko dziedzictwo dawnych epok. W 1960 roku dochody najbiedniejszych $20 \%$ mieszkańców Ziemi stanowiły 1/30 dochodów najbogatszych 20\%. Dziś ta proporcja to 1 do 74. Pomimo rosnącej produkcji przemysłowej rozmiary biedy na świecie ciągle się powiększają. Za główną przyczynę tego stanu rzeczy należy uznać zasady gospodarki neoliberalnej połączone z nieograniczoną, wręcz chorobliwą zachłannością finansową szefów korporacji, 
za wszelką cenę dążących do maksymalizacji zysków. Polaryzacja dochodów osiagająca tak wysoki stopień prowadzi do rozwarstwienia społeczeństwa, w którym szybko zaczynają się wyodrębniać dwie warstwy społeczne. Pierwszą stanowią właściciele firm i kadra zarządzająca. Jest to grupa stosunkowo nieliczna, ale dysponująca bardzo dużymi finansami oraz władzą, mogącą stanowić zagrożenie dla struktur regionalnych. Wynika to z faktu, że struktury regionalne swój rodowód wywodzą z tradycji demokratycznych, natomiast władza właścicieli korporacji pozbawiona jest demokratycznej legitymizacji, ponieważ wywodzi się ze struktur niewybieralnych. Drugą grupę stanowi warstwa coraz bardziej względnie ubożejąca, pozbawiona nadziei na lepsze jutro. W Stanach Zjednoczonych od kilkunastu lat obserwujemy systematyczny spadek wynagrodzeń pracowników niższego szczebla. W ciagu 30 lat w USA, pomimo wzrostu PKB o ponad 30\%, tygodniowe zarobki robotników zmniejszyły się o 19\% (Thurow 1999). Uwzględniając fakt, iż wzrost zarobków kadry zarządzającej nie idzie w parze z rachunkiem ekonomicznym, to głównym sposobem generowania zysków staje się redukcja etatów połączona z automatyzacją, robotyzacją i komputeryzacją, przenoszenie produkcji do krajów dysponujących tanią siłą roboczą oraz tzw. reinżyniering (reengineering), polegający głównie na redukcji etatów oraz stosowaniu niestandardowych form zatrudnienia.

Charakterystyczną cechą funkcjonowania korporacji transnarodowych jest brak korelacji między wynikami ekonomicznymi firmy a płacami kadry zarządzającej. W efekcie obserwujemy wyścig uposażeń managerów. Jeden z najlepiej zarabiających dyrektorów korporacji w 1997 roku uzyskał przychody w wysokości 102449000 rocznie, co daje 280682 dolarów dziennie („Business Week” z 21.04.1997). Obecnie dochody najbogatszych menedżerów liczone są w mln euro (tab. 3)

Tabela 3. Lista najbogatszych menedżerów w wybranych krajach świata w 2003 roku

\begin{tabular}{|c|c|c|}
\hline Imię i nazwisko & Szef zarządu & $\begin{array}{c}\text { Roczny dochód } \\
\text { w mln euro }\end{array}$ \\
\hline \multicolumn{3}{|l|}{ NIEMCY } \\
\hline Josef Ackermann & Deutsche Bank & 7,7 \\
\hline Wulf Bernotat & EON & 5,2 \\
\hline Jurgen Schrenpp & Daimler Chrysler & 5,2 \\
\hline Helmut Panke & BMW & 2,8 \\
\hline Bernd Pischetsrieder & Volkswagen & 2,7 \\
\hline Kai-Uwe Ricke & Deutsche Telecom & 2,6 \\
\hline \multicolumn{3}{|l|}{ USA } \\
\hline Sanford Weill & Citigroup & 24,6 \\
\hline Wiliam Harrison & Morgan Chase & 7,0 \\
\hline Jeffrey Immelt & General Electric & 6,0 \\
\hline Sam Palmisano & IBM & 5,7 \\
\hline Michael Eisner & Walt Disney & 4,9 \\
\hline Douglas Daft & Coca-Cola & 4,5 \\
\hline Richard Wagoner & General Motors & 4,2 \\
\hline Steven Ballmer & Microsoft & 0,7 \\
\hline \multicolumn{3}{|c|}{ WIELKA BRYTANIA } \\
\hline John Browne & $\mathrm{BP}$ & 4,5 \\
\hline Christopher Gent & Vodafone & 4,3 \\
\hline Terry Leahy & Tesco & 4,2 \\
\hline Fred Goodwin & Royal Bank of Scotland & 3,9 \\
\hline Jean-Pierre Garnier & GlaksoSmithKline & 3,5 \\
\hline Keith Whitson & HSBC Holdings & 3,3 \\
\hline Niall Fitzgerald & Unilever & 3,0 \\
\hline
\end{tabular}

Źródło: Uchatius 2004 
Pojawienie się na rynku stosunkowo mało licznej warstwy bardzo zamożnych ludzi prowadzi do powstania nowych relacji i procesów. Na płaszczyźnie gospodarczej doszło do paradoksu polegającego na tym, że majątek tylko jednego człowieka jest w stanie pobudzić do rozwoju gospodarkę regionalną.

Efektem polaryzacji dochodów jest - obserwowany już nawet w Polsce - proces zaniku warstwy średniej, stanowiącej swego rodzaju bufor pomiędzy warstwami o skrajnych dochodach. Rosnąca polaryzacja dochodów w dłuższym przedziale czasowym może owocować poważnymi napięciami społecznymi, którym nie zapobiegnie nawet polityka tittytainmentu (Martin, Schumann 2000).

Procesy globalizacji zmieniły warunki konkurowania. Zmieniła się rola kapitału intelektualnego, który w warunkach gospodarki jakościowej urósł do roli podstawowych czynników produkcji. Poszczególne regiony, chcące sprostać wymogom konkurencyjności, zmuszone są do kosztownych inwestycji w nowoczesne technologie, co w krótkiej perspektywie czasowej jest gwarantem przewagi konkurencyjnej jednego regionu nad drugim.

$\mathrm{Na}$ arenie międzynarodowej procesy globalizacji doprowadziły do powstania nowych form konkurencyjności, takich jak: wirtualne korporacje, specjalizacja produkcji czy dynamiczne sieci. W szczególności konkurencyjność typu wirtualne korporacje czy dynamiczne sieci może być przyczyną destabilizacji gospodarki regionalnej. Tworzenie tymczasowych aliansów strategicznych przez korporacje nie sprzyja stabilizacji gospodarczej regionów. Zdecydowanie bardziej pożądanymi formami konkurencyjności z punktu widzenia regionów są dynamiczne sieci oraz specjalizacja produkcji. Przedstawione nowe formy konkurencyjności pozwalają mieć nadzieję na dłuższe związanie kapitału korporacji z danym regionem.

Dla różnorodności regionów niebezpieczna jest unifikacja produktów. Zunifikowane towary zalewają poszczególne regiony, zagrażając tożsamości regionalnej. Powszechnie stosowana unifikacja produktów pozwala na:

- obniżenie kosztów promocji nowych towarów na rynku,

- standaryzację obsługi klienta,

- standaryzację produkowanych wyrobów,

- standaryzację marketingu,

- standaryzację konsumpcji,

- produkcję towarów na niespotykaną dotąd skalę.

$\mathrm{Z}$ tak doskonałą konkurencją produkcja regionalna towarów i handel nie związany z wielkim kapitałem skazane są na niepowodzenie. Aby sprostać wymogom rynku, regiony muszą być innowacyjne. Źródłem innowacji i nowoczesnych technologii są w głównej mierze korporacje transnarodowe. Nowoczesny region to taki, który ściśle współpracuje z korporacjami, umiejętnie niweluje negatywne skutki działalności KTN i wzmacnia pozytywne. Korporacje transnarodowe swoimi planami wybiegają daleko w przyszłość. Rodzaj i wielkość produkcji uzależnione są od specyfiki konsumentów. Warto zwrócić uwagę na fakt, że 75\% innowacji jest wynikiem analizy rynków, a 25\% - odkryć naukowych.

W warunkach otwartej konkurencji regionom coraz trudniej będzie równoważyć finanse. Rozwój telekomunikacji doprowadził do powstania rajów podatkowych (ryc. 1), do których uciekają firmy, artyści czy prywatni przedsiębiorcy. Legalizując swoją działalność w postaci spółek offshore, przyczyniają się do uszczuplenia lokalnych podatków oraz do transferu zysków poza region. 


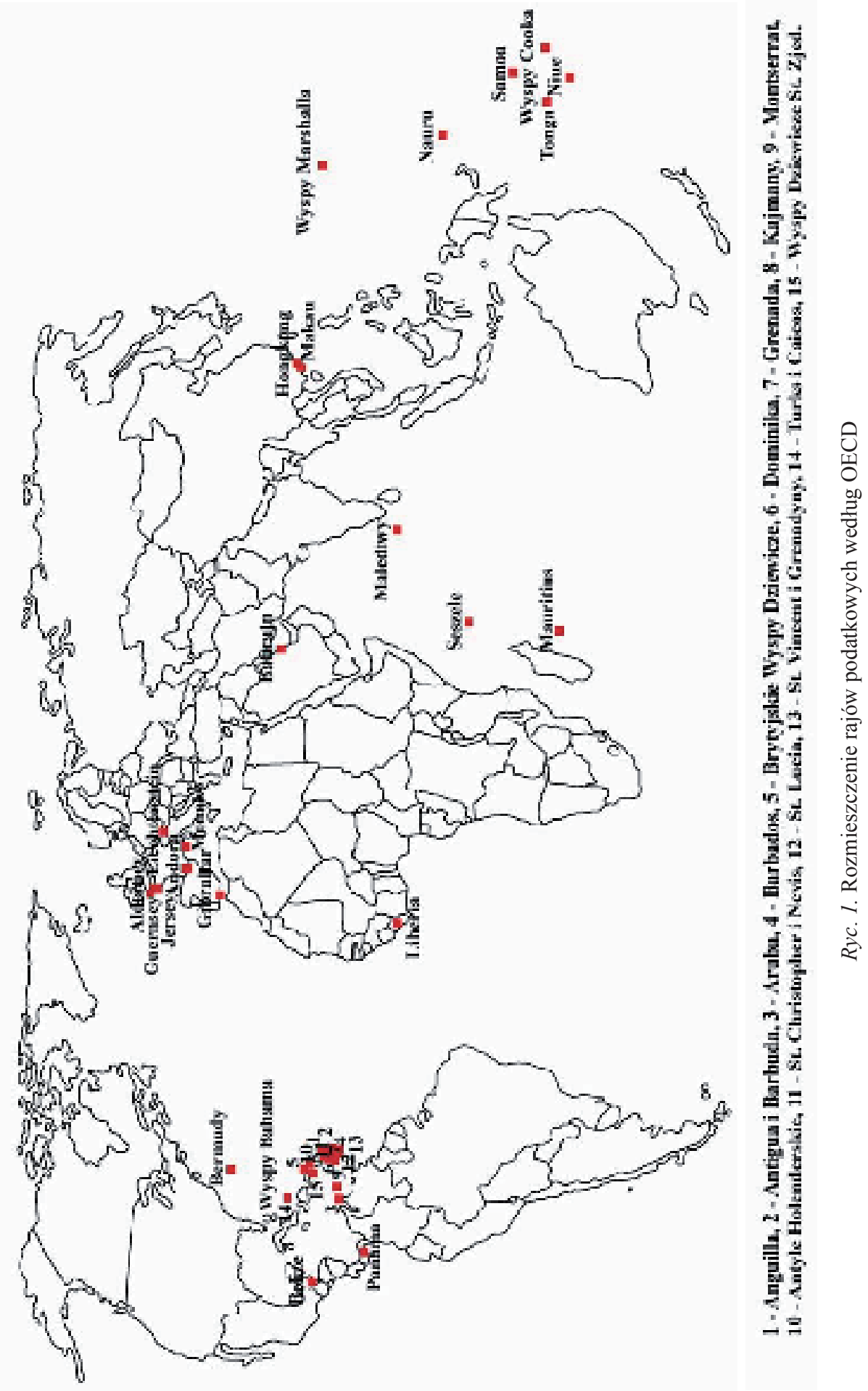


Kolejnym niebezpiecznym zjawiskiem dla regionu jest oddzielenie gospodarki od światowych finansów. Warto zwrócić uwagę na fakt, że handel światowy stanowi 2-3\% światowych przepływów finansowych.

\section{SPOŁECZNE KONSEKWENCJE PROCESÓW GLOBALIZACJI DLA REGIONU}

Konsekwencje procesów globalizacji natury społecznej stanowią wyzwanie dla szeroko rozumianego regionalizmu, a co się z tym bezpośrednio wiąże - zróżnicowania kulturowego danego kraju czy świata. Regionalizm jest kategorią łączącą człowieka z regionem. Tak jak region, regionalizm jest związany z konkretnym obszarem i jest on bardzo różnie definiowany. W ujęciu tradycyjnym, pod pojęciem regionalizmu rozumie się wszelką różnorodność, traktowaną jako odmienność ludzi, ich wyglądu, zwyczajów i obyczajów, siedlisk, czyli tych cech, które determinują określony typ kultury, najczęściej tej, która swymi korzeniami sięga daleko w przeszłość. Tak więc $\mathrm{w}$ tradycyjnym rozumieniu regionalizm jest uwarunkowany historycznie i określa takie tradycyjne cechy, jak ludowość czy folklor. Regionalizm jest niewątpliwie kategorią aksjologiczną (Skorowski 1998/1999), która na przestrzeni wieków wykształciła determinanty regionu.

Istnieją też ujęcia traktujące regionalizm w kategoriach ruchu społecznego, działającego na rzecz pielęgnowania i rozwijania lokalnej kultury czy dbania o lokalne oraz regionalne interesy, wyrażające uczestnictwo w życiu społecznym i politycznym danego kraju. Prezentowana grupa ujęć regionalizmu kładzie nacisk na działalność.

Kolejne grupy ujęć regionalizmu koncentrują się na przestrzeni „blisko siebie”, która jest niczym innym jak najbliższym środowiskiem geograficznym, w którym wychowuje się dana jednostka. Miejsca z naszej młodości czy dzieciństwa mają dla nas szczególną wartość, którą można nazwać lokalnością, swojskością, ojcowizną, domem czy małą ojczyzną. Prezentowane ujęcie regionalizmu odnosi się do subiektywnych wartości tkwiących w otaczającym nas środowisku geograficznym, nadającym specyficzny sens danemu miejscu.

Zakres pojęcia regionalizmu rozciąga się także na wytwory lokalnej społeczności. W tym ujęciu wszelkie wytwory człowieka (architektura, sztuka ludowa, stroje) określają konkretną rzeczywistość regionalną. Na koniec można przytoczyć jeszcze definicję regionalizmu według Donalda Tuska, który utożsamia regionalizm z pluralizmem, traktowanym jako przeciwieństwo totalitaryzmu. W obecnych czasach, wskutek działania procesów globalizacji, tradycyjne determinanty regionu ulegają pewnej modyfikacji oraz zacieraniu, natomiast $\mathrm{w}$ ich miejsce wykształcają się nowe.

Korporacje transnarodowe lansują nowy styl życia. Zmiana nawyków regionalnej społeczności dokonuje się już na etapie wprowadzania danego artykułu na lokalny rynek. Dysponując dużymi funduszami i doskonałymi fachowcami od reklamy, KTN za pośrednictwem prasy, radia i telewizji sztucznie rozbudzają potrzeby lokalnej społeczności. Treść prezentowanych reklam sprowadza się najczęściej do gloryfikowania idei zakupów. W ten sposób kreują nowy styl życia polegający na sugerowaniu, jakoby jedną z głównych wartości w życiu było robienie zakupów w danej sieci handlowej. Temu celowi służy koncentracja olbrzymich ilości towarów w hipermarketach. Kupujący bardzo często zaopatrują się w znacznie większe ilości towarów, niż wynoszą ich rzeczywiste potrzeby. Temu celowi służą różnorodne promocje cenowe, sprzedaż wiązana czy różnego typu konkursy. Hipermarkety 
są przy tym tak urządzone, aby można było traktować zakupy jako specyficzną formę aktywnego wypoczynku

Procesy globalizacji niosą ze sobą niebezpieczeństwo uniformizacji życia na wielu płaszczyznach. Efektem działania procesów globalizacji jest to, że w różnych częściach świata ludzie się podobnie ubierają (np. chodzą w jeansach czy garniturach), podobnie się odżywiają (np. jedzą pizzę czy hamburgery), pracują w podobnych albo tych samych firmach międzynarodowych, po pracy jeżdżą podobnymi samochodami na zakupy do wszechobecnych hipermarketów. W tych warunkach życie jednostki składa się z dwóch zasadniczych części: pracy i czasu wolnego, spędzanego najlepiej na zakupach w hipermarketach. Taki tok życia prowadzi do szeroko rozumianej uniformizacji, a główną wartością w życiu staje się utrzymanie pracy, często kosztem znajomych, przyjaciół czy nawet rodziny. Społeczeństwu funkcjonującemu w takich warunkach grozi unifikacja i bezkształtność, co może doprowadzić do zniszczenia wszelkiej różnorodności w życiu społecznym oraz utraty przez poszczególne jednostki podmiotowości. Pogłębiłaby się wtedy niepewność dotycząca nie tylko jutra, ale i dnia dzisiejszego. Człowiek pozbawiony podmiotowości, wyalienowany ze społeczeństwa, pozostawiony sam sobie, staje się aspołeczny, ze wszystkimi negatywnymi konsekwencjami.

Globalizacja sama w sobie nie jest zjawiskiem negatywnym, jednak niebezpieczne są skrajne zjawiska. Unifikacja życia ludzkiego na różnych płaszczyznach powoduje nie tylko zacieranie różnicy między poszczególnymi regionami, ale także zanik regionalizmów, które są głęboko zakorzenione w naturze człowieka. W dłuższym przedziale czasowym prowadzi to do utraty podmiotowości i tożsamości oraz wyobcowania (alienacji) poszczególnych jednostek funkcjonujących $\mathrm{w}$ danym regionie. W konsekwencji taki stan rzeczy może doprowadzić do zniszczenia różnorodnego dziedzictwa kulturalnego regionów. Jednak pomimo zagrożeń wynikających z procesów globalizacji regiony nie tylko nie zanikają, ale ewoluują, dostosowując się do wymogów współczesnego świata. Stopniowo zatracają cechy tradycyjnie kojarzone z regionem, a w ich miejsce wykształcają nowe wyznaczniki, wynikające z niepowtarzalnego charakteru danego miejsca oraz specyfiki obecnych czasów. Istotna różnica między tradycyjnymi a nowymi cechami regionów polega na tym, że w tradycyjnym ujęciu akcent został położony na cechy odnoszące się do konkretnej i obiektywnej rzeczywistości, do której należą m.in. historycznie uwarunkowany folklor wraz z cechami otoczenia, natomiast obecnie punkt ciężkości zostaje powoli przesuwany na cechy subiektywne, niemierzalne, należące do kategorii aksjologicznej.

Człowiek żyjący w środowisku geograficznym, spotykający się na każdym kroku z procesami unifikacji życia na wielu poziomach, odczuwa silną potrzebę wyróżnienia się z bezkształtnej masy jaką jest tłum, pragnie być niepowtarzalny i wyjątkowy. Taką niepowtarzalną okazję daje mu nowe ujęcie regionalizmu, oparte na takich cechach, jak niezależność administracyjna i działanie indywidualne oraz w ruchach społecznych na rzecz nowego regionu.

Odpowiedzią na zagrożenia wynikające z procesów globalizacji są odradzające się w nowej formie, dynamicznie się rozwijające i spontaniczne ruchy regionalne. Zrywają one $\mathrm{z}$ tradycyjnie ujmowanym regionalizmem, natomiast ich forma i zakres działania wyznaczają ramy regionalizmu w nowym ujęciu. Podobnie jak tradycyjnie rozumiany regionalizm, tak i nowy zasadza się bezpośrednio na konkretnym obszarze, jednak w tym przypadku nie będzie to tradycyjnie ujmowany region, ale obszar wyznaczony przez podziały administracyjne. Na przestrzeni ostatnich wieków dokonywane były wielokrotne zmiany granic admi- 
nistracyjnych, stopniowo przyczyniające się do rozmycia granic tradycyjnie pojmowanych regionów. W Polsce wszyscy znają takie tradycyjne regiony, jak Kaszuby, Mazowsze czy Śląsk, jednak obecnie zdecydowana większość ludzi miałaby duże problemy z wytyczeniem ich granic. Przykładów takich ruchów społecznych mamy bardzo wiele, wystarczy wspomnieć ostatnie zmiany podziału administracyjnego w Polsce, w trakcie którego różne grupy społeczne, reprezentujące niejednokrotnie sprzeczne interesy, skonsolidowały się w walce o utrzymanie co najmniej dawnej rangi przez swój region administracyjny. Podobny proces obserwujemy również na arenie międzynarodowej, gdzie przygraniczna ludność spontanicznie łączy się w walce o usunięcie barier granicznych, a w konsekwencji o rozwój niejednokrotnie zapóźnionych gospodarczo terenów przygranicznych. Starania te, wsparte polityką władz centralnych, doprowadziły do urzeczywistnienia idei euroregionów.

\section{NOWA REGIONALIZACJA JAKO KONSEKWENCJA PROCESÓW GLOBALIZACJI}

Procesy globalizacji działające z pominięciem nie tylko granic państwowych, ale także i regionalnych, przyczyniają się do powstania nowego typu regionu, który w swej istocie należy uznać za nowy odrodzony region ogólnogeograficzny. W czasach przenikania przez procesy globalizacji wszelkich granic, nowa koncepcja regionu wydaje się być nadrzędna w stosunku do koncepcji, wypracowanych przez poszczególne subdyscypliny geograficzne.

Podstawowym fundamentem, na którym opierają się cechy nowego regionu, jest obszar administracyjny. Na przestrzeni wieków wielokrotne zmiany administracyjne przyczyniły się do rozmycia granic tradycyjnych regionów, natomiast obecnie wyznaczają zasięg nowych aktualnych regionów, co szczególnie silnie uwidoczniło się podczas ostatnich zmian administracyjnych w Polsce. Kolejnym warunkiem rozwoju nowych regionów jest szeroka autonomia, rozumiana jako niezależność nie tylko administracyjna, ale i gospodarcza czy kulturalna. To właśnie na bazie niezależności administracyjnej rozwijają się nowe cechy regionu, do których możemy zaliczyć lokalną przedsiębiorczość przejawiającą się w walce o regionalne interesy (Skorowski 1998/1999; Zioło, Rachwał 2005). Autonomia regionu w podstawowych dziedzinach życia umożliwia jednostkom nieskrępowane działanie na wielu płaszczyznach. W ten sposób dochodzi do samorealizacji jednostek w nowych strukturach regionalnych, w trakcie której odnajdują swoją tożsamość. To właśnie działanie jest kategorią, która nie tylko wiąże człowieka z nowym regionem, wyznaczonym przez aktualne podziały administracyjne, ale sama staje się jednym z podstawowych wyznaczników nowego regionalizmu (Skorowski 1998/1999). Poprzez działanie jednostki łatwiej aklimatyzują się w nowym otoczeniu, odnajdują sens życia oraz mają możliwość wyróżnienia się ze zunifikowanego tłumu. Można zatem powiedzieć, że poprzez działanie jednostka ma możliwość rzeczywistego wpływu na oblicze własnego regionu. Świadomość celu działania utwierdza jednostkę w przekonaniu, że jest ona potrzebna, wyjątkowa, wyróżniająca się z jednorodności. Człowiek jako istota stadna nie potrafi funkcjonować poza grupą. Każda jednostka należy do jakiejś większej grupy - rodziny, regionu czy państwa. To właśnie działanie w grupie daje nam poczucie spełnienia. Współczesny człowiek może się identyfikować z regionem, państwem czy światem. Wraz ze spadkiem znaczenia państwa zmniejsza się jego autorytet, tak więc jednostkom pozostaje identyfikacja z regionem lub całym światem. Uwzględniając fakt, że procesy globalizacji poprzez unifikację odbierają jednostkom tożsamość, ze wszyst- 
kimi wynikającymi stąd konsekwencjami, to jedynym obszarem gwarantującym jednostce możliwość świadomej samorealizacji jest region w nowym ujęciu, rozumianym jako obszar administracyjny, posiadający dużą autonomię, na terenie którego rozwijają się regionalizmy w tradycyjnym i nowym ujęciu. Obszar administracyjny należy rozumieć nie tylko w kategoriach politycznych, ale przede wszystkim geograficznym. Zróżnicowanie elementów środowiska fizyczno-geograficznego i społeczno-ekonomicznego warunkuje lokalną specyfikę regionalizmów. Szeroko rozumiane działanie na płaszczyźnie ekonomicznej, kulturalnej, społecznej czy politycznej, wsparte regionalizmami, należy traktować jako odpowiedź jednostek na proponowany model życia przez KTN.

Reasumując, procesy globalizacji stanowią jednocześnie zagrożenie i szansę dla regionów. Konsekwencje polityczne i społeczno-gospodarcze tych procesów odciskają swoje piętno głównie na regionach, ponieważ to one bezpośrednio stykają się z działalnością korporacji transnarodowych. Z jednej strony bogate regiony w konsekwencji efektów kumulacyjnych w dalszym ciagu są atrakcyjne dla międzynarodowego kapitału, z drugiej natomiast przegrywają one rywalizację z regionami rozwijającymi się, których główną atrakcją jest stosunkowo dobrze wykwalifikowana, ale przede wszystkim tania siłą robocza.

Procesy globalizacji prowadzą do zacierania różnic między poszczególnymi regionami, ale i są podstawą, na której regiony budują swoją nową tożsamość. Obecnie obserwujemy w środowisku geograficznym proces zanikania tradycyjnie pojmowanych regionów. Główną przyczyną tego stanu rzeczy jest powstawanie nowych podziałów administracyjnych oraz zwiększająca się mobilność ludzi, związana ze wzrastającą swobodą przemieszczania się. Nie oznacza to jednak faktycznego zaniku regionów, lecz raczej ich modyfikację, polegającą na zacieraniu cech tradycyjnie pojmowanych oraz rozwijaniu tych, decydujących o niepowtarzalnym charakterze danego regionu. Cechy te bardzo często determinuja postawy ludzi przybyłych z zewnątrz oraz są na tyle mocne, że niejednokrotnie przebijają się ponad podziały polityczne. Odradzanie się współczesnych regionalizmów należy traktować jako odpowiedź ludności na konsekwencje procesów globalizacji. W przeciwieństwie do procesów globalizacji nowy regionalizm zaspokaja aspiracje społeczności lokalnych, dotyczące autonomii regionu, jego kulturalnego i gospodarczego rozwoju oraz indywidualne potrzeby mieszkańców.

\section{Literatura}

Chojnicki Z., 1999, Podstawy metodologiczne i teoretyczne geografii, Poznań.

Domański B., Guzik R., Micek G., 2003, Zróżnicowanie regionalne krajów Europy Środkowo-Wschodniej i jego zmiany w latach 1995-2000, Kraków.

Gawlikowska Hueckel K., 2002, Procesy rozwoju regionalnego w Unii Europejskiej, Gdańsk.

Gorzelak G., 1998, Regional and Local potential for transformation in Poland, Warszawa.

Hirst P., Thompson G., Cable V., 1995, Globalization and the Future of Nation State, „Economy and Society", no 2.

Jędrzejczyk D., 2002, Geograficzne aspekty globalizacji społeczeństwa i gospodarki, [w:] Z. Górka, A. Jelonek (red.), Geograficzne uwarunkowania rozwoju Małopolski, Kraków.

Kondracki J., 1995, O geografii regionalnej, „Przegląd Geograficzny”, 1-2.

Koter M. (red.), 1995, Region and Regionalism, Social and Economical Aspects, Łódź-Opole.

Koter M., 1995, Region and regionalism, Social and political aspect, Łódź-Opole. 
Makieła Z., Fedan R., 2006, Rzeszowski i krakowski obszar metropolitalny, Kraków.

Martin H.P., Schumann H., 2000, Pułapka globalizacji, Wrocław.

Massalski E., 1930, O zasadach wydzielania regionów, „Ziemia” XV, 2.

Ohmae K., 1995, The End of the Nation State. The rise of Regional Economies, „The Free Press”, New York.

Rykiel Z., 2006, Podstawy geografii politycznej, PWN, Warszawa.

Sala S., 2005, Procesy globalizacji ich konsekwencje dla regionów, [w:] M. Strzyż (red.), Perspektywy rozwoju regionu w świetle badań krajobrazowych, Polska Asocjacja Ekologii Krajobrazu, t. 12, Kielce.

Sala S., 2006, Agroturystyka a rozwój regionalny w dobie globalizacji, [w:] E. Pałka (red.), Gospodarka wielofunkcyjna ze szczególnym uwzględnieniem obszarów górskich, Kielce

Skorowski H., 1998/1999, Europa regionu. Regionalizm jako kategoria aksjologiczna, Warszawa.

Szymański W., 2001, Globalizacja - wyzwania i zagrożenia, Warszawa.

Thurow L., 1999, Przyszłość kapitalizmu. Jak dzisiejsze sity ekonomiczne ksztattuja świat jutra, Wrocław.

Uchatius W., 2004, „Die Zeit“, 23.09.

Wilczyński W., 1997, Ewolucja pojęcia regionu w literaturze geograficznej, „Rocznik Świętokrzyski”, Seria B - Nauki Przyrodnicze 24.

Wilk W., 1994, Miasto a region, [w:] Z problematyki badawczej polskiej geografii osadnictwa i ludności 1918-1939, Warszawa.

Zioło Z., Rachwał T. (red.), 2005, Przedsiębiorczość a wspótczesne wyzwania cywilizacyjne, „Przedsiębiorczość-Edukacja" nr 1, Kraków.

\section{Influence of globalization processes on a region}

The article presents the value of globalization processes in the development of a region. It distinguishes basic groups of the global processes, such as: development of the free market, development of transnational corporations, development of telecommunication, including: satellite television, the Internet (e-mail, IRC) and mobile phones web, and development of modern means of transport. The consequences of globalization processes are: limitation of governmental control, increase in the role of the speculation budget, diminishing of the middle class, increase in polarization of wages, explosion of illegal activities, rebirth of new regionalisms and increase in international tendencies. 